\title{
Juridical Review On The Instructions Of Governor Of Yogyakarta No. K/898/I/1975 On Uniformity Policy Of Land To The Granting Of A Non-Native Citizen
}

\begin{abstract}
Frans Ferbianto ${ }^{1}$ and Umar Ma'ruf ${ }^{2}$
Abstract. The purpose of this study was to: 1) To determine and analyze the implementation of The Instruction of DIY No. K/898/I/1975 which makes it difficult to obtain a non-native citizen property rights of land in Yogyakarta. 2) To determine and analyze the correlation instructions for DIY Regional Head No. $\mathrm{K} / 898 / \mathrm{I} / 1975$ with other legal regulations. The data used in this study are primary data, secondary data and data that can support tertiary study, which was then analyzed by descriptive analytical method. Based on the results of data analysis concluded that: 1 ) The provision granting land rights to a citizen Non-Natives in the province based instructions for DIY Regional Head No. K/898/I/A/1975 are not allowed to own land both farm and nonagricultural land with soil status Rights Owned. If a citizen Non Natives acquire land with the right then obliged to waive that right and land rights apply to the Regional Head of DIY with a given the building right (HGB). 2) The provision granting land rights to a Non-Native citizen in the province based instructions for DIY Regional Head No. K/898/I/1975.

Keywords: Judicial Review; Non-Native Citizen; Rights of Land.
\end{abstract}

\section{Introduction}

Land as part of the Earth that is the gift of God Almighty serves to meet the basic needs of human being. In the development of land has also become a lucrative investment tool, resulting in increased demand for land and buildings, and also the competition to acquire it, which in turn forces people to issue a greater sacrifice to get it. This leads to the land and the building to be very valuable, so that people who own land and buildings will be wherever possible to maintain ownership of the land ${ }^{3}$.

Land is something that has a value that is very important in people's lives, it is because the land has an economic value, as well as a magical-religious cosmic point of view of the Indonesian, he also frequently gives vibration in peace, and often cause shock in the community, and then he also a frequent cause obstacle in the implementation of national development. ${ }^{4}$

On this land, people can live and establish or continue their lives, in addition to the limited extent of land and can not be renewed, while the number of people continues to grow, which in turn will lead to competition in acquiring the land. Competition can be a good rivalry and competition is not good, especially if associated with the development of the construction that causes the soil has a high economic value and its value will continue to increase. Land can not be separated with humans for land is one

\footnotetext{
${ }^{1}$ Master of Notary's Student Sultan Agung Islamic University (UNISSULA) Semarang email : fransferbianto1987@gmail.com.

${ }^{2}$ Lecture of Faculty of Law UNISSULA

3 Pahala Marihot Siahaan 2003 Bea Perolehan Hak atas Tanah dan Bangunan Raja Grafindo Persada.Jakarta p. 32.

${ }^{4}$ John Salindeho 1998 Masalah Tanah Dalam Pembangunan Sinar Grafika Jakarta p. 38.
} 
important factor in human life, is a place of settlement land, where do human activities even after death also still need the land. ${ }^{5}$

Considering the background of agrarian, land has a very important meaning to people's lives in Indonesia, the more farmers in the countryside. ${ }^{6}$ Land serves as a place where citizens live and also provide livelihood for her land. ${ }^{7}$

Recognizing the significance of the aforementioned land, the state has arranged everything on the ground. With a decentralized system of government in Indonesia today, gives power to local governments to regulate the land in their respective regions. Hopefully, with the independence of the Local Government is able to develop the regions in accordance with the conditions and needs.

In this case the Special Region of Yogyakarta has a privilege, which was first set out in Act No.3 of 1950 on the Establishment of the Special Region of Yogyakarta, which then undergoes several changes, most recently by Act No.9 of 1955 on the Amendment Act No. 3 jo, No.19 Of 1950 on the Establishment of the Special Region of Yogyakarta, the Act is considered not complete it is then molded Act No.13 Of 2012 About Yogyakarta.

In terms of land, Yogyakarta also has the privilege, known as the Land of the Sultanate and the Duchy Land. Regarding tenure rights to land in Yogyakarta are the terms indigenous Indonesian citizen (citizen indigenous) and non-native Indonesian citizen. This term has been reinforced by the emergence of Governor DIY Circular PA.VIII / No.K.898 / I / A 1975 On Prohibition Properties For non-indigenous citizen.

Based on the background mentioned above, the authors are interested in doing further research to be manifested in a study entitled: "Juridical Review On The Instructions Of Governor Of Yogyakarta No. K/898/I/1975 On Uniformity Policy Of Land To The Granting Of A Non-Native Citizen"

\section{Research Methods}

The approach used in this study is primarily descriptive analytical approach. Descriptive analysis is research that describes an analysis of the existing findings. ${ }^{8}$ Descriptive analysis approach in this study, is the approach in terms of legislation and legal norms in accordance with the existing problems.

\section{Results And Discussion}

\subsection{The Instruction of DIY No. K/898/I/1975 On The Non Natives Citizen Causing Difficulties Obtaining Rights of Land In Yogyakarta}

At the time of independence on the basis of Law formation DIY (by Act No.3 / 1950 jo. By Act No.19 / 1950) DIY has the right and authority to manage his own family, including land affairs. Based on the authority and pending the establishment of the

\footnotetext{
5 Achmad Chulaemi 1992 Pengadaan Tanah Untuk Keperluan Tertentu Dalam Rangka Pembangunan Legal Issues Magazine No. 1 FH. Diponegoro University Semarang p. 9.

${ }^{6}$ IGN. Sugangga Kebijakan Pemerintah Kabupaten Dalam Hukum Pertanahan Adat di Wilayah Pantai Utara Jawa Tengah (Studi Kasus Penentuan Hak Tanah Timbul Dalam Masalah-Masalah Hukum) FH-UNDIP Scientific Magazine Vol. XXXI.No.2 April-June 2002 p. 49.

7 Soerjono Soekanto and Soleman B. Taneko 2001 Hukum Adat Indonesia Raja Grafindo Persada Jakarta p. 172.

${ }^{8}$ Soerjono Soekanto op.cit p 51
} 
Basic Law on Land of the Republic of Indonesia, Yogyakarta once formed the Provincial Regulation on land matters 9 .

Regulation ever established before the enactment of the BAL DIY ie Provincial Regulations Rijksblad, Instruction of Governor. Regional regulations, among others namely Regulation DIY/5/1954 of Land Rights in Regions of Yogyakarta based on Article 1 determines that: The right to land in the Region of Yogyakarta is set to Local regulation. This article specifies that all things associated with land rights in DIY will be governed by this Regulation caused not formation of the National law yet on the ground $^{10}$.

DIY Regulation 5 of 1954 pursuant to Article 4 governs the Property. Rights which originally was the "hak anganggo turun-temurun" (Javanese Lang.) the right to use that can be inherited "erfelijk Individueel gebruiksrecht"(Dutch Lang.) turns into the property because of rights is no longer appropriate to the circumstances as real-in fact, for the people's rights on his land, not just limited to " the right to wear it ", but may assign its rights to another party pay attention to the rules of origin applicable customary law in the region ${ }^{11}$,

Article 8 determines that the transfer of land rights and the provision of the agreements intended to rent out or provide an opportunity to use the land with property rights for small agricultural enterprises directly or indirectly to non-residents of the Republic of Indonesia is not valid. It can be concluded that in the DIY Regulation 5 of 1954 only gave the property of the citizen to citizen regardless Natives and Non Natives citizen.

Regulation No. 5 of 1954 is something that is very Monumental because Yogyakarta is a special region has prepared a regulation on Land when the Central Government when it has yet to make rules about who is the National Land.

BAL was born in 1984 under Presidential Decree No. 33 of 1984 on the Implementation of the Act No.5 of 1960 Fully in DIY and DIY Regulation No. 3 of 1984 on the Implementation of Applicable Fully Act No.5 of 1960 in DIY. Although essentially autonomous authority to switch the authority of deconcentration but it is possible the development of the sense of authority autonomy in the agrarian field for DIY which is based on the $\mathrm{e}^{12}$ :

- Act No.3 of 1950 on the Establishment of the Special Region of Yogyakarta, Article 4 paragraph (4) which provides that the household and other obligations than those mentioned in paragraph (1) is done by the Special Region of Yogyakarta been established under the Act this.

- Provisions Granting Land Rights To A citizen Non-Natives in Yogyakarta

In addition to historical reasons there are also economic reasons. Properties can not be granted to non-Natives citizen for the citizen of Chinese descent Non-Natives in particular is considered to have a strong economy so feared citizen Non-Natives will control the land in Yogyakarta while citizen who are considered to have a weak economy can not have any fear Properties in DIY.

\footnotetext{
9 Blog: Tri Widodo H Utomo Hukum Pertanahan Di Yogyakarta Sebelum dan Sesudah 1984 accessed on 6 March 2018.

10 Ibid

${ }^{11}$ I Gede Wiranata 2004 Hukum Adat Indonesia Perkembangannya dari Masa ke Masa Citra Aditya Bakti Bandung p. 20

12 Widhi Handoko 2014 Kebijakan Hukum Pertanahan Thafa Media Yogyakarta p. 35
} 
Then was born the Regional Government of DIY instructions for the uniform policy provided that the citizen Non-Natives can not be given the right to land in the province. Based on the instructions for DIY Regional Governor No. K.898/I/A/1975 About the Unification Policy granting land rights to a citizen Non Natives issued on March 5, 1975, which essentially contains the following:

If there is an Indonesian citizen non-Natives buy land property rights of the people, should be In progress as usual, is through a waiver, so that the soil back into the ground state directly controlled by the Regional Government of DIY and then the interested / release in order to submit an application to the DIY Regional Governor to get things right $^{13}$.

In essence, this instruction set of the Indonesian citizens who are citizens of nonNatives can not be Properties on land in Yogyakarta.

\subsection{Correlation Regional Government of DIY Instructions No. K/898/I/1975 With Other Legal Regulations}

Provisions in Regional Government of DIY Instruction No. K.898 / I / A / 75 This of course begs the question because in the Law has been set on the right of every citizen of Indonesia to acquire land rights and BAL has also been fully enforced in the province based on Presidential Decree No. 331984 but this provision remains in place until today without renewal or reconsideration.

Since the enactment of the BAL, when read in its implementation regulations BAL Act No.56 Prp. 1960 on the Establishment of Agricultural Land. Then there is the determination of maximum and minimum limits, but it is set up only for 1 (one) family does not include legal entities. UU no. 56 Prp. Determination of 1960 on Agricultural Land area is governed more by the PP 224 Of 1961. Then in the BAL dictum 4 A mention; former land unoccupied land and unoccupied since the enactment of BAL to state land. Then dictum B mention; provisions as mentioned in the dictum A provision will be further regulated in PP. PP is meant PP 224 Of 1961 . Now, if viewed in the provisions of Regulation No. 224 of 1961 was no object landerform, the state land, land marks of self-government, soils that exceeded the maximum, soils violate the prohibition of customary land. But the ground of self-government has not been regulated in the PP The 2241961 . What is meant in Dictum 4 B BAL associated with PP 224 of 1961, but it did not mention the autonomous land is governed by the PP. This raises a question related to how the autonomous land position in DIY. When talking of self-government in the province's land back into history, therefore looks like swirling related settings of the autonomous land in DIY This raises a question related to how the autonomous land position in DIY. When talking of self-government in the province's land back into history was, therefore looks like swirling related settings of the autonomous land in DIY This raises a question related to how the autonomous land position in DIY. When talking of self-government in the province's land back into history was, therefore looks like swirling related settings of the autonomous land in DIY ${ }^{14}$

13 Umar Ma'ruf 2014 Hak Menguasai Negara Atas Tanah \& Asas-Asas Hukum Pertanahan Unissula Press Semarang p. 74

${ }^{14}$ Lily Wibisono 2006 Etnik Tionghoa di Indonesia Mediatama Jakarta p. 41 


\section{Closing}

\subsection{Conclusion}

Based on the research results can be concluded as follows:

- The provision granting land rights to a citizen Non-Natives in the province based instructions for DIY Regional Head No. K.898 / I / A / 1975 are not allowed to own land both farm and non agricultural land with soil status Properties. If a citizen Non Natives acquire land with Hak then obliged to waive that right and land rights apply to the Regional Head of DIY with a given Hak Guna Bangunan (HGB).

- Provisions granting land rights to a citizen Non-Natives in the province based instructions for DIY Regional Head No. K.898 / I / A / 1975 when viewed under the principles of equal rights in the BAL that this provision is inconsistent or contrary to the principle of equality in the BAL that there is discrimination and class distinctions and contrary to the laws and regulations that exist on it despite the application of the provisions aimed at protecting citizen concern Natives can not be controlled if the citizen Properties Non Natives are allowed to control land Property Rights in DIY.

\subsection{Suggestion}

- Entry Instruction of Governor of Yogyakarta Special Region No. K.898 / I / 1975 was not in accordance with the conditions of the State of Indonesia pluralism as well as highly viscous feel of discrimination, especially the province of Yogyakarta is known as a student city and one of the tourist icon in Indonesia, so it should Instruction of Governor of Yogyakarta Special Region No. K.898 / I / 1975 is revoked.

- Yogyakarta Province as part of the Unitary Republic of Indonesia, to purge itself of legal products area should pay attention to Principle Applicability of the Act, it is necessary so that local regulations are issued does not conflict with legal regulations which are above, so that it can give the value of justice and the value of legal certainty for citizens.

\section{References}

[1] Achmad Chulaemi 1992 Pengadaan Tanah Untuk Keperluan Tertentu Dalam Rangka Pembangunan Legal Issues Magazine No. 1 FH. Diponegoro University Semarang.

[2] Act No.5 of 1960 on Basic Regulation of Agrarian.

[3] Book of the Civil Law (Civil Code)

[4] Government Regulation No. 40 of 1996 on leasehold, Broking and Right to Use Land.

[5] I Gede Wiranata 2004 Hukum Adat Indonesia Perkembangannya dari Masa ke Masa Citra Aditya Bakti Bandung

[6] IGN. Sugangga Kebijakan Pemerintah Kabupaten Dalam Hukum Pertanahan Adat di Wilayah Pantai Utara Jawa Tengah (Studi Kasus Penentuan Hak Tanah Timbul Dalam Masalah-Masalah Hukum) FH-UNDIP Scientific Magazine Vol. XXXI.No.2 April-June 2002 .

[7] John Salindeho 1998 Masalah Tanah Dalam Pembangunan Sinar Grafika Jakarta. 
[8] Lily Wibisono 2006 Etnik Tionghoa di Indonesia Mediatama Jakarta.

[9] Pahala Marihot Siahaan 2003 Bea Perolehan Hak atas Tanah dan Bangunan Raja Grafindo Persada Jakarta

[10]Regional Government of DIY Instructions No. K.898 / I / A / 1975

[11]Regulation of the Minister of Agriculture No. 3 of 1997 on provisions for the implementation of Government Regulation No. 24 of 1997

[12] Soerjono Soekanto and Soleman B. Taneko 2001 Hukum Adat Indonesia Raja Grafindo Persada Jakarta.

[13]Tri Widodo H Utomo Hukum Pertanahan Di Yogyakarta Sebelum dan Sesudah 1984 accessed on 6 April 2018.

[14]Umar Ma'ruf 2014 Hak Menguasai Negara Atas Tanah \& Asas-Asas Hukum Pertanahan Unissula Press Semarang.

[15]Widhi Handoko 2014 Kebijakan Hukum Pertanahan Thafa Media Yogyakarta. 